\title{
Chapter 11 \\ Return Migration from the Gulf Region to India Amidst COVID-19
}

\author{
S Irudaya Rajan and H. Arokkiaraj
}

\subsection{Introduction}

The pandemic has impacted the mobility of people across the globe in a way no other event in the past ever has. Travel restrictions and border sealing imposed by countries to curb the spread of the Covid-19 resulted in a large number of people being stuck in foreign nations, unable to return to their homes. The effect of such a move was felt not just by the migrant population living and working abroad but also by students studying abroad, tourists, and business travellers. Migrants felt the pandemic's effect in different ways, ranging from loss of jobs to cancellation or expiration of visas, thus rendering many unemployed and without any income to support them or send remittances to their families back home who depend on such remittances for their day-to-day expenditures. It is thus pertinent that we study the challenges faced by the emigrants, the assistance provided by the governments in the host and destination countries, and the policies that the home government has put forward to facilitate their rehabilitation and reintegrate them into the labour market of their country of origin. This chapter aims to shed lighton the above-mentioned aspects.

In a recent report, the IOM (2020a) defined stranded migrants in the context of Covid-19 as individuals outside of their country of habitual residence, wishing to return home but who are unable to do so due to mobility restrictions related to the pandemic. The number of migrants stranded abroad as of 13 July 2020was placed at three million, with the Middle East and North African Region reporting the largest number of stranded migrants (Table 11.1).

According to the International Migration Report 2019 (UN-DESA, 2019), India has the largest diaspora in the world at 18 million people; India's Ministry of

S I. Rajan $(\bowtie) \cdot H$. Arokkiaraj

The International Institute of Migration and Development (IIMAD),

Thiruvananthapuram, Kerala, India

e-mail: rajan@iimad.org 
Table 11.1 Estimated known cases of stranded migrants by IOM Region

\begin{tabular}{l|l}
\hline IOM region & Stranded migrants \\
\hline Asia and Pacific & 976,869 \\
\hline European Economic Area and Switzerland & 202,578 \\
\hline South America & 37,484 \\
\hline Middle East and North Africa & $1,257,053$ \\
\hline West and Central Africa & 5503 \\
\hline East and Horn of Africa & 2509 \\
\hline Southern Africa & 99,893 \\
\hline Central America, North America, Caribbean & 111,384 \\
\hline South Eastern Europe, Eastern Europe, Central & 58,181 \\
Asia &
\end{tabular}

Source: IOM (2020a)

Table 11.2 Top 10 hosts of overseas Indian populations (NRIs+PIOs)

\begin{tabular}{l|l|l|l}
\hline Country & NRIs & PIOs & Population \\
\hline United States of America & $1,280,000$ & $3,180,000$ & $4,460,000$ \\
\hline United Arab Emirates & $3,100,000$ & 4586 & $3,104,586$ \\
\hline Malaysia & 227,950 & $2,760,000$ & $2,987,950$ \\
\hline Saudi Arabia & $2,812,408$ & 2160 & $2,814,568$ \\
\hline Myanmar & 8991 & $2,000,000$ & $2,008,991$ \\
\hline United Kingdom & 325,000 & 1500,000 & $1,825,000$ \\
\hline Sri Lanka & 14,000 & $1,600,000$ & $1,614,000$ \\
\hline South Africa & 60,000 & 1500,000 & $1,560,000$ \\
\hline Kuwait & 928,421 & 1482 & 929,000 \\
\hline Mauritius & 10,500 & 884,000 & 894,500 \\
\hline Total & $13,459,195$ & $18,683,645$ & $32,100,340$
\end{tabular}

Source: Ministry of External Affairs, Government of India (Data given as of December 2018. Accessed from: https://mea.gov.in/images/attach/NRIs-and-PIOs_1.pdf)

Note: $N R I=$ Non-resident Indians (an individual who is a citizen of India but is residing in a foreign country and holds a valid Indian passport). PIO = People of Indian Origin (Foreign Citizens except for nationals of Pakistan and Bangladesh, who have either held an Indian passport at any point in time or their parents/grandparents/great-grandparents were permanent residents of Indiaor are spouses of an Indian citizen)

External Affairs puts their number at 32 million (Table 11.2). These patterns also vary according to the state of origin and destination countries (IOM, 2020c; Ratha et al., 2020a, b). Table 11.3 shows the number of Indians who travelled to different countries for employment in the last 3 years. In addition to this data, the number of Indian workers travelling to Gulf countries in the past 5 years is on the decline (Table 11.4).

However, country-specific and occupational-specific figures may differ (Kumar \& Rajan, 2014; Singh \& Rajan, 2016). For example, Kerala still maintains the trend of sending the maximum number of nurses to Saudi Arabia over the years. On the other hand, the number of female domestic workers emigrating to Gulf countries from different states of India has declined in the past 6 years (Table 11.5). 
Table 11.3 Number of Indians gone abroad for employment, 2017-2019

\begin{tabular}{l|l}
\hline Year & No. of Indians departed on employment visa \\
\hline 2017 & $34,72,494$ \\
\hline 2018 & $28,10,789$ \\
\hline 2019 & $25,43,577$ \\
\hline
\end{tabular}

Source: Compiled by the authors from the annual reports of the Ministry of External Affairs and the eMigrate website of the Government of India

Table 11.4 Number of Indian workers emigrated through Protector General of Migrants and eMigrate, 2014-2020

\begin{tabular}{l|l}
\hline Year & Numbers emigrated \\
\hline 2014 & 805,005 \\
\hline 2015 & 784,152 \\
\hline 2016 & 520,938 \\
\hline 2017 & 391,024 \\
\hline 2018 & 340,157 \\
\hline 2020 & 368,043 \\
\hline
\end{tabular}

Source: Compiled by the authors from the annual reports of the Ministry of External Affairs and the eMigrate website of the Government of India

Table 11.5 Data on Indian female domestic worker emigrated by state, 2014-2019

\begin{tabular}{l|l|l|l|l|l|l}
\hline State & 2014 & 2015 & 2016 & 2017 & 2018 & 2019 \\
\hline Andhra Pradesh & 965 & 112 & 51 & 41 & 27 & 85 \\
\hline Karnataka & 43 & 66 & 68 & 44 & 28 & 20 \\
\hline Kerala & 470 & 597 & 497 & 388 & 238 & 149 \\
\hline Tamil Nadu & 60 & 95 & 86 & 69 & 52 & 27 \\
\hline Telangana & 38 & 36 & 29 & 16 & 8 & 6 \\
\hline
\end{tabular}

Source: Compiled by the authors from the annual reports of the Ministry of External Affairs and the eMigrate website of the Government of India

In recent decades, emigration from India has been largely concentrated towards the Gulf region, followed by the US. However, the nature of emigration differs; unlike migration to Western countries led by mostly highly educated and skilled migrants, migration to the Gulf is of a temporary nature, and this results in large scale return migration to India from the region. An important aspect of migration to the Gulf is the predominance of unskilled labourers (Rajan, 2017, 2018, 2019; Rajan \& Oommen, 2020a; Rajan \& Saxena, 2019). The temporary nature of the move along with the nature of skill possessed by the emigrants makes them an extremely vulnerable group, especially during a crisis like the pandemic (Rajan, 2020a, b, 2021; Rajan et al., 2020, 2021). As per an official statement made by the Minister of State for External Affairs, in the Lok Sabha, of the total requests for repatriation received by the government, the largest number was from the Gulf region (Table 11.6). 
Table 11.6 Repatriation requests received (as of 16 September 2020)

\begin{tabular}{|c|c|}
\hline Country & Total requests \\
\hline United Arab Emirates & 305,056 \\
\hline Qatar & 120,600 \\
\hline Oman & 100,604 \\
\hline Saudi & 90,119 \\
\hline Kuwait & 80,732 \\
\hline United States of America & 69,030 \\
\hline United Kingdom & 44,759 \\
\hline Bahrain & 41,763 \\
\hline Nepal & 26,379 \\
\hline Singapore & 21,832 \\
\hline Australia & 21,486 \\
\hline Canada & 20,385 \\
\hline Germany & 17,322 \\
\hline Russia & 15,616 \\
\hline Malaysia & 14,934 \\
\hline Ukraine & 14,585 \\
\hline Kyrgyzstan & 14,249 \\
\hline France & 12,002 \\
\hline Nigeria & 11,694 \\
\hline Bangladesh & 10,996 \\
\hline Other Countries & 108,379 \\
\hline Total Requests & 1162,522 \\
\hline
\end{tabular}

Source: Lok Sabha Q\&A Session, 16 September 2020 (Ministry of External Affairs (2020), Lok Sabha, Unstarred Question No.479, Answered on 16/09/2020 by MEA, Shri V. Muraleedharan. Accessed 29 December 2020.)

A large number of Indian migrants are in the low-income category with temporary jobs. This 'temporariness' of Indian migrants working in the informal sector abroad contributes to their highly precarious living conditions during the pandemic. It is also estimated that around 586,183 Indian students are studying in 91 foreign countries. ${ }^{1}$ India ranks second after China in the number of international students in the United States and United Kingdom, while in 2018, India ranked first and fourth, respectively, in the number of foreign students in Ukraine and China. In Germany, India heads the rankings with regard to labour migration as compared to China in quantitative terms (Graf, 2019).

India was proactive in rescuing and bringing back its citizens from regions that were heavily affected by the pandemic, with rescue operations conducted in February 2020 for Indians stranded in China, Italy, and Iran. Following the rise in cases in India, the Government of India adopted a strategy of a nationwide

\footnotetext{
${ }^{1}$ Ministry of Human Resource Development (2018), Department of Higher Education, Government of India. Lok Sabha, Unstarred Question No.2219. Answered on 1.1.2018. Accessed 29 December 2020.
} 
lockdown and sealing of international borders for a 21-day period to curb Covid-19's spread. This brought all such rescue missions to a halt, stranding many Indians in different countries across the world. India, as one of the largest migrant-sending nations, had a herculean task ahead of it in terms of bringing those stranded Indians back home.

With the government having announced complete restrictions on mobility both within and outside the country, several petitions were filed in the Supreme Court at the beginning of the lockdown period to bring back the stranded Indians. The Supreme Court dismissed the petitions and advised stranded migrants - migrant workers, students, and tourists - to stay in the respective foreign countries until the lockdown ended. The Government of India subsequently extended the nationwide lockdown until 3 May, prompting new petitions, moston behalf of Indian migrant workers stuck in the Gulf countries. Their number is estimated to be between eight and ten million; Kerala alone accounts for 2.1 million emigrants in Gulf countries, as per the Kerala Migration Survey 2018 (Rajan, 2020c; Rajan \& Zachariah, 2019; Zachariah et al., 1999). The state was a leading voice for the repatriation of stranded Indians, many of whom faced visa issues or lived in precarious conditions in labour camps without proper hygiene and unable to observe of proper social distancing which often led to a spike in Covid-19 cases in many of these labour camps (Rajan \& Oommen, 2020b).

Some media reports also mentioned that around 19 Indians were stuck in transit at international airports for the duration of the lockdown when India sealed its international borders. One petition also claimed that some of the migrant workers who tested positive for Covid-19 were denied treatment in hospitals. The Government of India finally decided to bring back the Indians stuck in countries across the world by launching a massive evacuation programme called the Vande Bharat Mission, which was introduced on 7 May 2020.

\subsection{Differing Paths, Differing Problems}

It can be observed that the pattern of international migration from India is diverse where workers originate from different Indian states and migrate to different countries. They are engaged in different occupations as white collar and blue-collar jobs or are students, which points to their distinct category or visa status.

The economic repercussions of the pandemic and lockdowns in most countries were felt acutely by migrant workers and professionals around the world. Many suffered job losses and had to struggle to maintain their visa statuses in their respective countries. In no region was this impact more severe than among temporary migrant workers in the Gulf. Low-income Indian migrant workers in Gulf countries are either partially or fully excluded from social security and health insurance benefits (Chowdhury \& Rajan, 2018; Rajan, 2016). Being infected by the virus would have led to increases in their health expenses, taking a huge toll on the meagre savings on which they were relying upon for sustenance abroad after being rendered jobless. 
As a result, for these migrants, the financial woes would have been a bigger problem than the virus itself if they were left stranded in a foreign country without adequate assistance. Moreover, this would also push their families in India into greater difficulty because of their dependence on remittances from these workers.

Visa expirations too were an issue that some of these migrants faced, exacerbating the problems of stranded emigrants. It is a common misconception that most of the people stranded abroad have a wealthy background. Several scholars in Migration Studies have pointed out that workers from low economic backgrounds tend to migrate in the Indo-Gulf migration corridor to enhance their financial status. Therefore, what was witnessed was a large number of Indians in the Gulf, who are low- and middle-income migrant workers wanting to return to India to overcome the crisis. Another issue that came up was the issue of wage theft among migrant workers. As the pandemic and its economic effects became more apparent, it emerged that a number of employers had unlawfully dismissed workers and were withholding essential benefits and even wages of migrant workers - who then had to head home with empty hands and very few options for recourse (Piper \& Foley, 2021).

Despite the assurances from the Central Government that every Indian abroad is safe and secure and their situation constantly monitored by the Indian embassies, several public interest litigations pertaining to Indians abroad were filed in the Supreme Court and the Kerala High Court to urge the respective governments to act quickly to bring back stranded migrants. Meanwhile in the Gulf countries, the kafala sponsorship method of recruiting workers - which gives local individuals or companies sponsorship permits to employ foreign laborers in GCC countries (except Bahrain) for whom the sponsor covers travel expenses and provides housing, often in dorm-like accommodations or, in the case of domestic workers, the sponsor's home - made these migrant employees even more vulnerable as they live at the mercy of their sponsors. This was not the case with other countries, where the imposition of travel restrictions and halting the issuance of work permits had left some migrants unable to reach their place of employment and with no source of income (IOM, 2020b: Le Coz \& Newland, 2021). There is also a need to consider that there are different categories of Indians holding different types of visas who are seeking help. In the US, for instance, the non-resident Indian community faced several issues in terms of consular services as the passport renewals were being withheld. Indians in the US include students, young persons on Optional Practical Training (OPT) for F-1 students, persons on temporary visas like the H-1B visa, and B-2 visa. There was a fear that their visas would expire during the lockdown without an extension, which would render their status as 'undocumented'. Meanwhile, the community came together to create awareness sessions with attorneys, immigration attorneys, consul generals of different Indian posts.

The migration crisis in India resulting from the lockdown measures implemented to curb the pandemic's spread has revealed several anomalies in terms of economic and social security provisions for both its internal and international migrant workers during the times of crisis. These vulnerable workers are either unaware of or not in a position to utilise the existing legal provisions to safeguard themselves from the problems they face with their employers or at their workplace, such as retrenchment 
at a short notice. In fact, in the case of international migrants, there are no legal provisions to safeguard the rights of these workers in times of crisis. Further, the suspension of consular services by Indian embassies on account of Covid-19 and the virtual nature of providing emergency services made the situation for Indians even worse, as they found it difficult to contact the authorities for immediate help. At this juncture, the Indian embassies in Gulf and other countries are the only point of contact for stranded Indians, and this necessitates their being proactive by enabling them in such circumstances instead of temporarily suspending embassy services.

However, it was in these trying times that the Indian government initiated the largest repatriation mission in its history.

\subsection{Assistance Amidst Travel Restrictions}

In the initial stages of the lockdown, the lack of initiative from the Government of India towards the evacuation of its own citizens stranded abroad was in stark contrast with other countries. The government cited 'lack of resources' as a reason for not evacuating Indian citizens (The Hindu, 2020). However, there was also a dichotomy between India's previous and current approach to tackle the issue of evacuation that points towards a lack of willingness, despite the pressure from stranded Indians and other stakeholders. During the travel restrictions due to the lockdown, Indian citizens were airlifted from the worst Covid-19-affected countries like China, Italy, and Iran. In view of this, the question arises as to why India had not evacuated its distressed citizens in the Gulf and other countries. The US, which at that point of time had been one of the worst-hit countries in the world, had embarked upon mass evacuation of their citizens stranded in 17 countries. Similarly, other countries affected by the pandemic such as Germany also made efforts to evacuate their citizens stranded abroad. The Government of Kerala made repeated requests to the Central Government for arrangements to evacuate Non-Resident Keralites from the Gulf region citing reasons such as expiring work visas, inability to sustain themselves without work, and pregnant women and children. Kerala was prepared to provide necessary medical support for the returnees. Overall, this raises questions about the lack of such an initiative by India to evacuate all distressed Indians and not just some.

The central government's reluctance to bring back the migrants was not received well by the Gulf nations. Several sent a stern message to the Indian government; the United Arab Emirates, for instance, threatened to enforce tight restrictions on countries failing to take back their migrants and also restructure or suspend its Memorandum of Understanding (MoU) on labour with them, impose limits on the recruitment of workers from these countries, and apply a quota system in recruitment operations (Nasrallah, 2020). Similarly, Kuwait demanded that India evacuate migrants, given the large number of infections in the community. Mounting pressure from the migrant-hosting countries, the emigrants, but also their states back 
home, forced the Government of India to launch the Vande Bharat Mission to evacuate stranded migrants in a phased manner.

Kuwait announced an amnesty for foreign workers in the country from 1 April 2020 to 30 April 2020 (The Wire, 2020). Its government allotted specific slots to different countries for the repatriation of foreign workers according to their nationality. The first week was allotted to Philippines to make use of the amnesty. In coordination with the Philippine embassy in Kuwait, the Philippine government evacuated its citizens from Kuwait. The slot allotted to India for evacuating its citizens was 16-20 April 2020. There were many Indian citizens willing to avail this amnesty and return to India, but the Supreme Court's ruling and the Central Government's response was a setback for them. During the same period, the United Arab Emirates government had also shown readiness to allow the evacuation of Indian citizens, but the Indian government was reluctant to take any initiative to help their own citizens stranded in difficult circumstances.

As the pandemic began spreading across the world between February and April, the Government of India embarked upon multiple missions to rescue its citizens from the countries severely hit by the pandemic, starting with missions to Wuhan in February. A mission was also launched in February to rescue members stranded aboard the Diamond Princess Cruise ship in Japan. In March, the missions were directed to Iran and Italy, which were severely affected by the pandemic, with a rescue mission conducted in Iran as late as 22March 2020 to bring back stranded Indians. Along with stranded Indians, the government also successfully evacuated nationals of Myanmar, Bangladesh, Maldives, China, and the US, among other countries, from the Hubei province in China.

\subsection{Vande Bharat Mission (VBM)}

The Government of India declared a complete lockdown on 24 March 2020 to contain the pandemic and slow down the transmission rates. The lockdown was initially for a period of 21 days, which was further extended. During this period, the country came to a complete stand still as educational institutions, industries, trade, transportation, and government offices shut down. The lockdown included a total ban on international and inter-state travel. As the boundaries of the nation closed, these nationals along with Indians who had travelled abroad prior to the lockdown were stranded in different parts of the world, unable to return to India. The lockdown also ended the missions undertaken by the government to rescue Indians stranded abroad.

In April 2020, the government announced the Vande Bharat Mission for the safe passage of Indian nationals back to the homeland. This mammoth effort was an evacuation initiative jointly coordinated by the Ministry of External Affairs, Ministry of Home Affairs, Ministry of Civil Aviation, and all state governments (Ministry of Civil Aviation, 2020a; Ministry of External Affairs, 2020a; Ministry of Home Affairs, 2020). The missions were to be carried put primarily by air, but the Indian Navy was also involved in the initial stages of the evacuation process. The Indian 
Navy had named the evacuation process 'Samudra Setu' and had deployed ships to the Gulf to rescue stranded Indians in the region. A Standard Operating Protocol was framed for the mission, with the safety and health of the returnees given priority everywhere and at all points in time. Embassies, high commissions, and consulates were tasked with preparing the list of distressed nationals; they communicated with Indian nationals through social media, set up helplines, and played a key role in the mission. Stranded Indians were advised to register in portals for their return and the passengers were instructed to follow health protocols issued by the Ministry of Health, Ministry of Civil Aviation, and Indian Medical Association throughout the journey. Upon reaching India, all arrivals were screened at the airport and instructed to quarantine for a period of 14 days. The State governments were advised to arrange for testing, monitoring, and helping the returned nationals during their quarantine period and afterwards (Wadhwa, 2020).

There was an overwhelming number of registrations in the repatriation portals that were opened by the Government of India, with the official figures at over 1.16 million on 16 September 2020 (Ministry of External Affairs, 2020d, e). The first phase of the mission from Abu Dhabi was flagged off on 7 May 2020. In the initial phase, rescue missions were undertaken jointly with the Indian Air Force, Indian Navy, along with Air India and its subsidiary, the Air India Express (Ministry of Defence, 2020). A total of seven phases of the Vande Bharat Mission had been completed by late October, with the eighth phase beginning on 1 November 2020. As of 17 December, 3,840,000 Indian nationals had been repatriated through the Vande Bharat Mission (Table 11.7). The missions were initially concentrated to the Gulf region where majority of stranded Indians were located, but in the later phases, repatriation missions were carried out in other parts of the world as well.

As per a government release on data pertaining to Indians repatriated through the Vande Bharat Mission, at 16September 2020, 1.4 million Indians had been repatriated through different modes, with the government expecting an additional 1,20,000 Indians returning to the country by the end of the Phase 6 . Of them, 12,69,549 people have been flown back (Table 11.8); the majority were returned from Gulf nations, notably United Arab Emirates, followed by Saudi Arabia, Kuwait, Oman,

Table 11.7 Vande Bharat Mission: phases and repatriation

\begin{tabular}{l|l|l|l}
\hline Phases & Period & Mission countries & Cumulative no of repatriates \\
\hline I & 7 May - 15 May 2020 & 12 & 12,708 \\
\hline II & 16 May - 10 June 2020 & 47 & 165,375 \\
\hline III & 12 June - 2 July 2020 & 43 & 503,990 \\
\hline IV & 3 July - 31 July 2020 & 29 & 900,000 \\
\hline V & 1 August - 31 August 2020 & 22 & $1,300,000$ \\
\hline VI & 1 September - 31 September 2020 & 24 & $1,645,000$ \\
\hline VII & 1 October - 31 October 2020 & 24 & $2,157,000^{\mathrm{a}}$ \\
\hline VIII & 1 November - 31 December 2020 & 24 & $3,840,000^{\mathrm{b}}$ \\
\hline
\end{tabular}

Source: Compiled from the Media briefings and press releases of the Ministry of External Affairs ${ }^{a}$ Figure as of 6 November 2020

${ }^{b}$ Figure as of 17 December2020 
Table 11.8 Repatriates by country under Vande Bharat Mission

\begin{tabular}{l|l|c}
\hline Country & Repatriates & Percentage \\
\hline Bahrain & 24,704 & 1.94 \\
\hline Canada & 13,342 & 1.05 \\
\hline France & 16,337 & 1.29 \\
\hline Germany & 19,744 & 1.56 \\
\hline Kuwait & 90,759 & 7.15 \\
\hline Oman & 85,498 & 6.73 \\
\hline Qatar & 104,444 & 8.23 \\
\hline Saudi Arabia & 163,851 & 12.91 \\
\hline Singapore & 24,867 & 1.96 \\
\hline United Arab Emirates & 457,596 & 36.04 \\
\hline United Kingdom & 39,141 & 3.08 \\
\hline United States of America & 77,305 & 6.08 \\
\hline Total Repatriated under VandeBharat & $1,269,549$ & \\
Mission & & \\
\hline
\end{tabular}

Source: Ministry of External Affairs, 2020c

Table 11.9 Repatriates by state of arrival under Vande Bharat Mission

\begin{tabular}{l|l|c}
\hline State & Repatriates & Percentage \\
\hline Andhra Pradesh & 33,413 & 2.63 \\
\hline Bihar & 33,708 & 2.66 \\
\hline Delhi & 228,705 & 18.02 \\
\hline Gujarat & 24,502 & 1.93 \\
\hline Karnataka & 61,380 & 4.84 \\
\hline Kerala & 372,053 & 29.31 \\
\hline Maharashtra & 96,796 & 7.63 \\
\hline Punjab & 32,017 & 2.52 \\
\hline Rajasthan & 32,709 & 2.57 \\
\hline Tamil Nadu & 110,246 & 8.69 \\
\hline Telangana & 66,518 & 5.24 \\
\hline Uttar Pradesh & 116,009 & 9.14 \\
\hline India (Total) & $1,269,549$ &
\end{tabular}

Source: Rajya Sabha Q\&A session, 22 September 2020

and the US. Looking at the state data, we see that close to $29 \%$ of Indians who have come back have returned to Kerala, followed by Delhi, Uttar Pradesh, Tamil Nadu, and Maharashtra (Table 11.9).

Similarly, data obtained from a government statement in the Rajya Sabha on returnees from the Gulf, of the total number of Indians who have returned, more than $21 \%$ are from Kerala; indeed, more than half of the Bahrain returnees and onethird of Oman returnees are from Kerala (Table 11.10). 
Table 11.10 Gulf repatriates under Vande Bharat Mission ${ }^{\mathrm{a}}$

\begin{tabular}{l|l|l|l}
\hline Country & Arrived in Kerala & Total Indians arrived & Percentage of Keralites \\
\hline United Arab Emirates & 70,329 & 435,682 & 16.14 \\
\hline Bahrain & 12,726 & 23,957 & 53.12 \\
\hline Kuwait & 14,541 & 87,305 & 16.65 \\
\hline Oman & 30,545 & 81,953 & 37.27 \\
\hline Qatar & 27,445 & 101,182 & 27.12 \\
\hline Saudi Arabia & 34,088 & 154,103 & 22.12 \\
\hline Total & 18,9674 & 88,4182 & 21.45
\end{tabular}

as per domicile declaration done on MEA online registration and the statement made by Minister of State for External affairs in Parliament on 17 September 2020 (Ministry of External Affairs, 2020b)

Though the rescue mission undertaken by the Government of India, the biggest of its kind, has largely been deemed successful, returned nationals have had to face several issues related to the repatriation due to of the government's delayed response - from authorities in the host countries to issues pertaining to the refunds and surcharges for return tickets cancelled because of the lockdown. Apart from these issues, the repatriation mission turned out to be a costly affair for many of the migrants - most of them were returning because they had lost their jobs - due to the exorbitant fares charged for repatriation flights on some of the routes. Media reports suggested the fares charged under the Vande Bharat Mission were higher than normal, especially on tickets from Europe and the Americas, where fares have been reported to be two or even three times higher (Chowdhury, 2020; Smitha, 2020).

After many reports of returnees having to bear the cost of the flights, Indian Civil Aviation Minister, HS Puri clarified that the 'rates were reasonable when compared to repatriation flights of other countries' (Smitha, 2020). This did little to assuage passengers' concerns though. For instance, there were reports of one-way fares from the UK and the US being charged at the same rate as round-trip flights (sometimes even three times that of a normal ticket). Similarly, ticket prices from other popular destinations such as the United Arab Emirates ranged between 1300 and 1700 AED (Arab Emirates Dirham) for a ticket that would normally cost about 900 AED (ibid.).

In fact, the commercial aspect of these flights also came into question when the US Department of Transportation limited the number of Vande Bharat flights into the US in June, citing 'unfair and discriminatory trade practices'. The US government alleged that while Vande Bharat flights were operating from the US and charging fares, US airlines had been barred from entering India. They alleged that this created a 'competitive disadvantage for American carriers' (Levin, 2020). These high costs of repatriation put the humanitarian angle of the mission under a harsh light as they are out of the reach of many of the less privileged migrants, who would have had to stay in their destinations. 


\subsection{Case Study: Undocumented Indian Workers in Kuwait During COVID-19}

On 14 June 2020, Kumar (pseudonym) received a call from Indian embassy in Kuwait, which he recounted over the telephone in a conversation with us:

First they asked my name, then where I was working and was I willing to go back to home.
They then asked about the nature of my problem and after gathering the remaining details,
they asked me whether I had money to purchase the flight tickets. They told me, to my
surprise, that only if I said "yes" would they proceed with the call, and if "no" then they
would immediately disconnect the call. Furthermore, if I said "yes" then they mentioned
that I would have to undergo Covid-19 testing followed by 14-day quarantine upon arrival.
Only if I agreed to these conditions would they inform us on how to book the tickets and
then they would note my name. Based on this, we had to decide on whether to go home or not.

This narration is telling about the plight and vulnerability of poor blue-collar workers willing to return from the Gulf countries. For example, 78 Kuwaiti dinars (approx. Rs 19,100) were charged for the ticket in the special flight to Chennai from Kuwait, where they were placed in institutional quarantine - paid or free. The cost for those choosing paid quarantine facilities was around Rs 1500 per day for each person.

In the case of Kuwait, India did not only have to deal with stranded Indians with legal status but also with thousands of undocumented workers who registered for amnesty to leave the country without incurring any penalty - as had been decreed in April by the Kuwait government. These migrants were being housed in shelters provided by Kuwait. The repatriation of Pakistan and Philippine nationals had begun in the first week of April, but Indian expatriates who had applied for amnesty had been languishing at the shelters waiting for the India to devise evacuation plans.

Thousands of undocumented Indian workers applied for the amnesty announced by Kuwait and desperately waited for more than two weeks in the shelter homes. Furthermore, undocumented migrants had to wait for Emergency Certificates (EC) ${ }^{2}$ issued by the Indian embassy, meantime living outdoors in unsafe and poor housing conditions in the absence of any legal status. ECs are valid for a single journey to India and the certificate does not exempt a holder from immigration or visa regulations. Holders must guard the EC and submit it along with the application for a duplicate passport upon arrival in India.

It is unclear how many Indians wereinfectedwithCovid-19 in Kuwait, but reports state their number was second to infections among Indian migrant workers in Singapore (Laskar, 2020).

Thousands of Indians in Kuwait lost their jobs due to the pandemic; most undocumented migrants work in construction, hotels, sheep herding, gardening, and other

\footnotetext{
${ }^{2} \mathrm{An}$ Emergency Certificate is issued to an Indian national for his/her return back to India if there is no valid travel document with the person or he/she is an illegal resident abroad, for example in UAE. https://www.cgidubai.gov.in/page/emergency-certificates/\#: :text=Consular\%20 $\%$ E2\%80\%BA\%20EMERGENCY\%20CERTIFICATES-,Emergency\%20Certificates,be $\% 20$ issued $\% 20 \mathrm{in} \% 20$ such $\% 20$ cases.
} 
low-profile jobs. Generally, low-skilled migrant workers from India enter Gulf countries legally, slipping into undocumented status later as they lack the necessary identification documents after fleeing an abusive employer who confiscates their passport. Due to other reasons such as job loss, visa overstay, or non-renewal of visa, the workers lose their legal status. In the end, there is a sizeable number of undocumented Indian migrants in the Gulf region who were not widely discussed during the pandemic. Undocumented migrants are entirely excluded from both economic and social security as they lack legal status.

Some undocumented migrants received their ECs to leave Kuwait but had no accommodation or basic amenities until returning home. As the EC is only valid for a short period and these migrants have no other legal documents for staying in Kuwait, their daily lives are fraught with risks as they are under the surveillance of Kuwait police and could face persecutions because of their undocumented status. Moreover, they don't have money to pay accommodation, food, and return tickets as the pandemic left them unemployed, many for more than four months. These circumstances add to their physical and mental stress as their families in India worry about their situation. Moreover, these low-skilled migrants are illiterate and have no bargaining power with employers.

In Kuwait, unrest has slowly mounted among the Indian workers in shelters as they started taking to social media to narrate their plight and desperation to return to India. Many do not have money to recharge mobile phones and contact their families or even money to meet basic needs. Moreover, they have inculcated the feeling that they are treated poorly when compared with other Indian citizens who can afford to return India. Meanwhile, Kuwait has offered free tickets to undocumented workers on its national carriers. However, at the time of writing, this category of Indian workers was still struggling to return home as the Indian government had yet to respond to Kuwait's offer (Bhattacherjee, 2020; The Wire, 2020).

Kuwait has been imposing stringent regulations to contain the virus's spread. Undocumented migrants awaiting assistance from the Indian embassy to use the amnesty are entirely dependent on the Kuwait government for necessary medical facilities and other daily needs. Furthermore, if infected with Covid-19, the big question is from where they would seek medical attention: Kuwait's healthcare system may face severe stress from contagion in shelters as happened in Singapore's cramped migrant worker dormitories.

\subsection{Rehabilitation and Beyond: Is There a Model in Place?}

The huge influx of migrants in the wake of the pandemic throws up several questions for the future of migration and migration policy in India. Due to the large number of emigrants coming back to India, the country may face underemployment or unemployment situations especially among the skilled workforce. Moreover, Indian migrants contribute over $\$ 80$ billion in remittances to the country every year- a vital inflow for the development of individuals, families, communities, 
societies, and the country as a whole. The pandemic and return of migrants to India should raise concerns regarding rehabilitation, re-integration, and more importantly, re-migration once conditions normalise that the government must address very seriously.

At the beginning of the crisis, there was very little talk about the plight of international migrants, given the immediate concern about internal migrants (Rajan, 2021; Rajan et al., 2020, 2021). Indeed, when the government announced its flagship five-stage Aatmanirbhar Bharat (Self- Sufficient India) scheme to ameliorate the plight of migrants within India and revive the economy, it did not mention international migrants (Rajan, 2020d). However, with the plight of international migrants becoming more visible - and through efforts and pressure from state governments and civil society organisations - the central government launched a few initiatives. The Skilled Workers Arrival Database for Employment Support (SWADES) scheme, for example, is a joint venture of the Ministry of Skill Development and Entrepreneurship, Ministry of External Affairs, and Ministry of Civil Aviation to create a database of returned migrants according to skill and experience and thus meet human resource demands of Indian and foreign companies. It is aimed at all the citizens from around the world, across Emigration Clearance Required (ECR) and Emigration Clearance Not Required (ECNR) categories. This was done to facilitate reintegration of migrant workers into the labour market and promote employment opportunities. To facilitate employment opportunities, details of SWADES registrations have also been integrated with Skill India's ASEEM (Aatmanirbhar Skilled Employee Employer Mapping) portal which was launched on 10 July 2020. Furthermore, all data regarding Indians returning under Vande Bharat Mission was also shared with relevant state governments on a real-time basis (Ministry of Civil Aviation, 2020b).

\subsection{A Kerala Model of Rehabilitation?}

Kerala, which is one of India's largest migrant-sending states, took the lead in pushing for the welfare of its overseas citizens - which is unsurprising given the massive economic and social capital that they garner for the state. Given its large and prominent diaspora, particularly in the Gulf countries which contribute almost $30 \%$ of the state's GDP in remittances alone, Kerala has had long and proactive steps in migration policy and diaspora outreach, which precedes even that of the Indian government (Rajan, 2020c). Thus, from the start, Kerala had pushed for the repatriation of the stranded migrants, coupled with mounting pressure from interventions made by the Indian Supreme Court and multiple Public Interest Litigations and appeals made by stranded Indians abroad; this led the government to eventually announce the Vande Bharat Mission. International migrants constitute an integral part of Kerala society and their rehabilitation and reintegration are vital for an economy that otherwise suffers from a modest growth rate and high unemployment. Kerala has, 
therefore, announced a slew of schemes that would aid in this effort - more than any other state or even the central government.

Such rehabilitation schemes and projects were launched through a separate web portal for Non-Resident Keralites via NORKA Roots, the Kerala government's agency for the welfare of Non- Resident Keralites. Kerala is a developed state in India where the contribution of the non-resident Keralites to the economy is highly remarkable. The government had initiated a relief fund for the emigrants who reached Kerala after 1 January 2020. The amount of ₹25 (crore) was distributed to 50,000 eligible people by the end of August. Each eligible return emigrant received ₹5000 as a one-time benefit through this scheme (NORKA Roots, 2020a). An NDPREM (NORKA Department Project for Returned Migrants) scheme was also extended to provide seed capital funding of up to ₹30,00,000 for entrepreneurs. Along with 'Meat Products of India', this scheme extends service and benefits to migrants who returned during the pandemic. Banks will sanction loans for modest enterprises as per the business interest and the terms and conditions of the bank. For prompt repayment, $15 \%$ subsidy on capital and 3\% rebate on interest of loan are offered for the first four years. The applicants must have at least 2 years working experience abroad. The returnees can even form societies, trusts, and companies to apply under this scheme (NORKA Roots, 2020b).

'Santhwana' is a relief scheme that aims to provide financial support for returned migrants. It offers aid to meet the financial needs of returned migrants such as marriage assistance, purchase of physical aids to combat disabilities, medical treatments, etc. Applicants are eligible only if family income is less than ₹ 1,00,000 per year and they had been a migrant for a minimum of 2 years. Also, to avail the scheme, the period after return should not have exceeded the period of his working in a foreign country or 10 years, whichever is shorter. Santhwana provides up to Rs 1 lakh as death assistance, Rs 50,000 for the treatment of critical medical conditions, Rs 20,000 for the treatment of other kinds of diseases, Rs 15,000 for marriage assistance, and Rs 10,000 to buy wheelchair, crutches, artificial limbs, etc. Additionally, under the scheme all returned migrants who still have a valid passport, valid visa, and have tested positive for Covid-19 receive₹10,000 as emergency financial assistance (NORKA Roots, 2020a).

The government of Kerala also launched the Dream Kerala Project, which primarily aims to open new possibilities and opportunities for returned Keralites and fully utilise their skills and expertise. This project envisages crowdsourcing of ideas under the mentorship of young government officials and professionals experienced in the international job market. The expert committee will evaluate the proposals and make recommendations to the respective departments. Through successful implementation of these projects and schemes, government relief enhances welfare and thereby ensures the betterment of the Non-Resident Keralite community. However, these projects and schemes are still works-in-progress and whether they achieve their objectives is still a major question - one on which the future of the state depends. 


\subsection{Concluding Remarks}

Although the initiatives undertaken by India's government to bring back stranded migrants have been pronounced as rather successful, the lack of initiative at the beginning of the lockdown and the delay in bringing the stranded emigrants back have come under a lot of scrutiny. What was witnessed was a lack of coherence in the government strategies to bring back these emigrants and differences on this issue between the positions among the states and the central government. The biggest challenge for the government now lies in the reintegration of these migrant workers into the domestic market. With the SWADES and ASEEM policies now in place to try and reintegrate the skilled migrants, the government should also look at policies and programmes that would cater to the skill development of the returned migrants. It should also adopt measures that would enable them to re-migrate, with better skills, which would then broaden their prospects to newer regions for migration and help enhance their bargaining power.

The government's under-preparedness at such a time of crisis and the lack of coherence among the states and the central government can be partly attributed to the lack of a national policy on migration, which countries like Sri Lanka already had in place. The policies followed by countries like Sri Lanka, Philippines, and Malaysiaen courage migration from the states unlike India, which is not open about encouraging migration, even though India is one of the largest emigrant-sending and remittance-receiving countries in the world. What is also of utmost importance now is the need for proper data on emigration from the country that would have allowed better management of the pandemic's effects. The right policies, backed by accurate evidence and data, are the need of the hour and would help chart a plan for the way forward and equip India to face such future crises in a better manner.

\subsection{Postscript}

In the middle of the first wave, MEA revised and reduced the minimum referral wages of Indians who work in Qatar, Bahrain, Oman, and the UAE to \$200 to \$245 for Kuwait, to $\$ 196$ for domestic sector workers, and to \$324 for Saudi Arabia. Meanwhile, to bypass the travel ban on India, hundreds of migrants transited through UAE to reach Saudi Arabia and Kuwait for jobs. There were also many other hurdles for stranded Indian workers whose visas had expired to move within and outside the Gulf. Workers who returned to India during the first wave were desperate to return to ensure their livelihoods, but the Covid-19 second wave hampered their travel plans as key destination countries for workers such as UAE and Saudi Arabia extended ban on flights from India. Newly arriving migrants in the Gulf countries under the VBM flights have to undergo mandatory quarantining, and the cost of it at the destination countries restricted workers' mobility from India. On the other hand, not all the returnees want to leave their home until the pandemic curve 
is flattered and are waiting for travel and mobility restrictions to be eased. Other issues have also been observed, such as unscrupulous recruitment agents making false job promises for nurses, who are exempted from travel restrictions. Migrants in Gulf countries continue to suffer greater financial strain as they face job and wage loss. As we write this during the Covid-19 second wave in India, almost all Indian labour-receiving countries in the Gulf have imposed a travel ban from India. In Kuwait, for example, only outbound flights are allowed to select states in India. In case of UAE, a complete travel ban has been imposed. Recently, the Kerala Government has started to issue vaccination certification with passport number, with the hope that this will enable migrant workers to get travel clearance in the future.

\section{References}

Bhattacherjee, K. (2020). Kuwait offers to airlift stranded Indians. The Hindu, May 1. https://www. thehindu.com/news/national/kuwait-offers-to-airlift-stranded-indians/article31484743.ece.

Le Coz, C., \& Newland, K. (2021). Rewiring migrant returns and reintegration after the COVID-19 shock. Migration Policy Institute.

Chowdhury, A. (2020). Rough weather for those boarding VandeBharat. Economic Times, June 8. https://economictimes.indiatimes.com/industry/transportation/airlines/-aviation/rough-weather-for-those-boarding-vande-bharat/articleshow/76251419. cms?utm_source $=$ contentofinterest\&utm_medium=text\&utm_campaign $=$ cppst.

Chowdhury, M., \& Rajan, S. I. (Eds.). (2018). South Asia migration in the Gulf. Palgrave Macmillan.

Graf, J. (2019). Migration monitoring: Educational and labour migration to Germany. Annual Report 2018 (Reports on Migration and Integration. Series 1). Research Centre for Migration, Integration and Asylum at the Federal Office for Migration and Refugees.

IOM (International Organization for Migration). (2020a). Covid-19 impact on stranded migrants. https://www.iom.int/sites/default/files/documents/issue_brief_return_task_force.pdf.

IOM (International Organization for Migration). (2020b). Understanding the migration \& mobility implications of COVID-19. Grand-Saconnex, Switzerland. Retrieved fromhttps://www.iom. int/sites/default/files/our_work/ICP/MPR/covid-19_analytical_snapshot_10_-_economic_ impacts_on_migrants.pdf.

IOM (International Organization for Migration). (2020c). World migration report 2020. International Organization for Migration.

Kumar, S. K., \& Rajan, S. I. (2014). Emigration in 21 st century India: Governance, legislation and institutions. Routledge.

Laskar, R. H. (2020). Singapore, Kuwait record highest number of Indians infected with Covid-19. The Hindustan Times, April 27. https://www.hindustantimes.com/india-news/singapore-kuwaitrecord-highest-number-of-indian-covid-19-cases/story-nNW338HhJdwSu93GC2aCOM.html.

Levin, A. (2020). US restricts Air India's 'Vande Bharat' flights citing 'unfair' limits on its airlines. The Print, June 23.

Ministry of Civil Aviation. (2020a). 8,503 Indians return from abroad in 43 flights under Vande Bharat Mission since 7th May 2020. Press Release. https://pib.gov.in/PressReleasePage. aspx?PRIP=163475

Ministry of Civil Aviation. (2020b). Government to conduct skill mapping of citizens returning from overseas. Press Release. https://pib.gov.in/PressReleasePage.aspx?PRID=1628976. 
Ministry of Defence. (2020). INS magar departs male with Indian citizens embarked. Press Release. http://pib.gov.in/PressReleasePage.aspx?PRIP=1622776.

Ministry of External Affairs. (2020a). Lok Sabha, Unstarred Question No: 4124, Answered on 18/03/2020 by MEA, Shri V. Muraleedharan.

Ministry of External Affairs. (2020b). Rajya Sabha, Unsatarred Ouestion No. 577, Answered on 17/09/2020 by MEA, Shri V. Muraleedharan.

Ministry of External Affairs. (2020c). Rajya Sabha, Unstarred Question No.1369, Answered on 22/09/2020 by MEA, Shri V. Muraleedharan.

Ministry of External Affairs. (2020d, September 17). Transcript of virtual weekly media briefing by the official spokesperson. https://www.mea.gov.in/media-briefings.htm?dtl/33008/Transcript_ of_Virtual_Weekly_Media_Briefing_by_the_Official_Spokeserson_17_September_2020.

Ministry of External Affairs. (2020e, October 01). Transcript of virtual weekly media briefing by the official spokesperson. https://mea.gov.in/media-briefings.htm?dtl/33106/Transcript_of_ Virtual_Weekly_Media_Briefing_by_the_Official_Spokesperson_01_October_2020.

Ministry of Home Affairs. (2020). Government of India to facilitate return of Indian Nationals stranded abroad. Press Release. https://pib.gov.in/PressReleasePage.aspx?PRIP=1620953

Nasrallah, T. (2020). Covid-19: UAE considers imposing restrictions on these countries. Gulf News, April 12. https://gulfnews.com/uae/government/ covid-19-uae-considers-imposing-restrictions-on-these-countries-1.1586688517978.

Norka Roots. (2020a). ₹25 crores distributed to 50,000 returned migrants. Press Release. https://norkaroots.org/documents/20126/6200333/pr+25-08-2020.PDF/ bcc67aa0-6e4f-ecb2-c371-94c0148c22d5.

Norka Roots. (2020b). Meet products of India join hands with NORKA ROOTS. Press Release. https://norkaroots.org/documents/20126/6200333/PR+23-07-2020.pdf/b1dc1cef-bf24-452c-4 $6 \mathrm{~b} 5-5 \mathrm{~b} 4 \mathrm{~b} 5 \mathrm{~b} 249 \mathrm{~b} 6 \mathrm{e}$.

Piper, N., \& Foley, L. (2021). The other pandemic for migrant workers: Wage theft. Open Democracy, January 12. https://www.opendemocracy.net/en/pandemic-border/ other-pandemic-migrant-workers-wage-theft/.

Rajan, S. I. (2016). India migration report 2016: Gulf migration. Routledge.

Rajan, S. I. (2017). South Asia-Gulf migration corridor: An introduction. In South Asia migration report 2017: Recruitment, remittances and reintegration (pp. 1-19). Routledge.

Rajan, S. I. (2018). Demography of the Gulf Region. In M. Chowdhury \& S. I. Rajan (Eds.), South Asia migration in the Gulf (pp. 35-59). Palgrave Macmillan.

Rajan, S. I. (2019). The crisis of Gulf migration. In C. Menjivar, M. Ruiz, \& I. Ness (Eds.), The Oxford handbook of migration crisis (pp. 849-868). Oxford University Press.

Rajan, S. I. (2020a). Migrants at a crossroads: COVID-19 and challenges to migration. Migration and Development, 9(3), 323-330.

Rajan, S. I. (2020b). COVID-19-led migrant crisis: A critique of policies. Economic and Political Weekly, 55(48), 13-16.

Rajan, S. I. (2020c). India migration report 2020: Kerala model of migration surveys. Routledge.

Rajan, S. I. (2020d). No package for internal migrants. In The stimulus package in five installments does it make the economy more self-reliant? (Commentary on India's economy and Society Series) (Vol. 15, pp. 23-25). Centre for Development Studies.

Rajan, S. I. (2021). Pandemic and migrants: Missed opportunities and the road ahead. In S. Baru (Ed.), Beyond COVID's shadow: Mapping India's economic resurgence (pp. 254-268). Rupa Publications.

Rajan, S. I., \& Oommen, G. Z. (2020a). Asianisation of migrant workers in the Gulf countries. Springer.

Rajan, S. I., \& Oommen, G. Z. (2020b). The South Asian-Gulf migrant crisis. The Hindu, July $29 . \quad$ https://www.thehindu.com/opinion/op-ed/the-south-asian-gulf-migrant-crisis/article32215146.ece.

Rajan, S. I., \& Saxena, P. C. (2019). India's Low-skilled Migration to the Middle East. Palgrave Macmillan. 
Rajan, S. I., \& Zachariah, K. C. (2019). Emigration and remittances: New evidence from the Kerala migration survey 2018 (Working Paper 483). Centre for Development Studies.

Rajan, S. I., Sivakumar, P., \& Srinivasan, A. (2020). The COVID-19 pandemic and internal labour migration in India: A 'Crisis of mobility'. Indian Journal of Labour Economics, 63(4), 1021-1039.

Rajan, S. I., Rajagopalan, R., \& Sivakumar, P. (2021). Chapter 6: The long walk towards uncertainty: The migrant dilemma in times of COVID-19. In A. Hans et al. (Eds.), Migration, workers and fundamental freedoms: Pandemic vulnerabilities and states of exception in India. Routledge.

Ratha, D., De, S., Kim, E. J., Plaza, S., Seshan, G., \& Yameogo, N. D. (2020a). Migration and development brief 32: COVID-19 crisis through a migration lens. KNOMAD-World Bank.

Ratha, D., De, S., Kim, E. J., Plaza, S., Seshan, G., \& Yameogo, N. D. (2020b). Migration and development brief 33: Phase II: COVID-19 crisis through a migration lens. KNOMADWorld Bank.

Singh, A. D., \& Rajan, S. I. (2016). Politics of migration: Indian emigration in a globalised world. Routledge.

Smitha, N. (2020). Exorbitant ticket fares make special flights unaffordable for stranded students. Deccan Chronicle, June 8. https://www.deccanchronicle.com/nation/current-affairs/080620/ exorbitant-ticket-fares-make-special-flights-unaffordable-for-stranded.html.

The Hindu. (2020). Not feasible to evacuate all Indian citizens from abroad, says Government. https://www.thehindu.com/news/national/coronavirus-not-feasible-to-evacuate-all-indiancitizens-from-abroad-says-government/article31334918.ece.

The Wire. (2020, May 2). Kuwait reiterates offer to transport undocumented Indian workers for free. https://thewire.in/diplomacy/india-kuwait-undocumented-workers-amnesty-transport.

UN Department of Economic and Social Affairs. (2019). International Migration Report 2019. https://www.un.org/en/development/desa/population/migration/publications/migrationreport/ docs/InternationalMigration2019_Report.pdf.

Wadhwa, A. (2020). Welcome back. India Perspectives. https://www.indiaperspectives.gov.in/ en_US/welcome-back/.

Zachariah, K. C., Mathew, E. T., \& Rajan, S. I. (1999). Impact of migration on Kerala's economy and society (Centre for Development Studies, Working Paper No. 297). Centre for Development Studies.

Open Access This chapter is licensed under the terms of the Creative Commons Attribution 4.0 International License (http://creativecommons.org/licenses/by/4.0/), which permits use, sharing, adaptation, distribution and reproduction in any medium or format, as long as you give appropriate credit to the original author(s) and the source, provide a link to the Creative Commons license and indicate if changes were made.

The images or other third party material in this chapter are included in the chapter's Creative Commons license, unless indicated otherwise in a credit line to the material. If material is not included in the chapter's Creative Commons license and your intended use is not permitted by statutory regulation or exceeds the permitted use, you will need to obtain permission directly from the copyright holder.

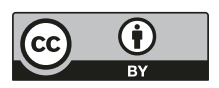

